\title{
Effect of follicular aspiration just before ovulation on corpus luteum characteristics, circulating progesterone concentrations and uterine receptivity in single-ovulating and superstimulated heifers
}

\author{
L O'Hara, S Scully, V Maillo ${ }^{1}$, A K Kelly, P Duffy, F Carter, N Forde, D Rizos ${ }^{1}$ and P Lonergan \\ School of Agriculture and Food Science, University College Dublin, Belfield, Dublin 4, Ireland and \\ ${ }^{1}$ Departamento de Reproduction Animal, INIA, Madrid, Spain \\ Correspondence should be addressed to P Lonergan; Email: pat.lonergan@ucd.ie
}

\begin{abstract}
The aim of this study was to investigate, in unstimulated and superstimulated heifers, the effect of follicle aspiration just before ovulation on corpus luteum $(C L)$ development, circulating progesterone $\left(P_{4}\right)$ concentrations and the ability of the uterus to support embryo development. Following follicle aspiration or ovulation timed from GNRH administration, CL development was assessed by daily ultrasonography, and CL function was assessed in terms of the capacity to produce $P_{4}$ and the expression of genes involved in steroidogenesis in luteal tissue. The capacity of the uterine environment to support conceptus development was assessed following transfer and recovery of in vitro-produced embryos. Follicular aspiration just before the expected time of ovulation leads to a significant reduction in CL diameter, $\mathrm{CL}$ area and area of luteal tissue. This was associated with a decrease in circulating $\mathbf{P}_{\mathbf{4}}$ in both unstimulated and superstimulated heifers. Follicle aspiration leads to a reduction in conceptus length and area on day 14 in unstimulated heifers only. Follicle aspiration leads to a reduction in the expression of $L H C G R$ in luteal tissue from unstimulated heifers compared with those in which the CL formed after ovulation. Superstimulation significantly reduced the expression of STAR in luteal tissue in both ovulated and follicle-aspirated heifers. In conclusion, in stimulated and unstimulated heifers, aspiration of the preovulatory dominant follicle(s) just before expected ovulation interferes with the subsequent formation and function of the $\mathrm{CL}$, in terms of size and $\mathrm{P}_{4}$ output and this, in turn, is associated with a reduced capacity of the uterus to support conceptus elongation in unstimulated heifers.

Reproduction (2012) 143 673-682
\end{abstract}

\section{Introduction}

Controlled ovarian hyperstimulation $(\mathrm{COH})$ is a routine procedure used in assisted reproduction to stimulate the growth of multiple follicles in naturally single-ovulating species such as cattle and humans. In cattle, this procedure is used to increase the number of offspring from genetically valuable females; such females are stimulated with gonadotropins to induce the ovulation of a variable number of follicles, artificially inseminated with semen from a high genetic merit sire and the resulting embryos are non-surgically flushed from the uterus 7 days later for transfer to surrogate recipients or cryopreservation and transfer at a later date. Similarly, many women undergoing in vitro fertilisation (IVF) treatment undergo $\mathrm{COH}$ to induce the development of multiple dominant follicles. In contrast to cattle, multiple mature oocytes are recovered by transvaginal follicle aspiration just before ovulation, inseminated in vitro with partner/donor sperm and then embryos are transferred back to the same women, often in the same cycle. Because of this fact, the endocrinology associated with $\mathrm{COH}$ and the environment of the reproductive tract following such procedures are important.

In women, stimulated IVF cycles are associated with a defective luteal phase in almost all cases due to the supraphysiological concentrations of steroids associated with $\mathrm{COH}$, which lead to suppression of pituitary LH secretion (reviewed by Fatemi et al. (2007) and Messinis et al. (2009)). Exogenous supplemental progesterone $\left(\mathrm{P}_{4}\right)$, often extending up to week 12 , is a common practice in IVF-stimulated cycles because of the associated luteal phase defects (Kolibianakis \& Devroey 2002, Pritts \& Atwood 2002, Kolibianakis et al. 2003). Although the benefit of $\mathrm{P}_{4}$ administration as luteal phase support has been well documented in IVF (Fatemi et al. 2007), a question surrounds the optimum time for its discontinuation (Griesinger 2011) based on the results of a retrospective uncontrolled study of 400 pregnancies (Schmidt et al. 2001) and two randomised trials (Nyboe Andersen et al. 2002, Kyrou et al. 2011), 
which suggest that supplementation beyond 4 weeks of gestation is unnecessary.

One other explanation put forward to explain luteal dysfunction is the removal of granulosa cells during follicular aspiration and the consequent effect on corpus luteum $(\mathrm{CL})$ formation and function $\left(\mathrm{P}_{4}\right.$ secretion; Garcia et al. 1981, Vargyas et al. 1986). Similar findings were reported in non-human primates (Kreitmann et al. 1981). In contrast, Kerin et al. (1981) reported that aspiration of follicular fluid from the immediately preovular follicle did not impair the steroid secretion capacity of the subsequent $\mathrm{CL}$ compared with that in spontaneously ovulating women.

It is clear that luteal tissue can be formed following follicular aspiration before ovulation; however, follicular diameter at aspiration can influence the subsequent CL formation and function (Hinrichs et al. 1991, Mozzaquatro et al. 2011). Follicular diameter at ovulation and the duration of proestrus have been identified as sources of variation in conception rate in cattle (Lamb et al. 2001, Peters \& Pursley 2003, Perry et al. 2005, Mussard et al. 2007). Premature ovulation of a dominant follicle with GNRH can reduce the size of the ovulatory follicle, decrease subsequent luteal function and reduce fertility, perhaps associated with compromised uterine receptivity given the unequivocal role of $\mathrm{P}_{4}$ in creating an optimal uterine environment for pregnancy establishment (Clemente et al. 2009, Forde et al. 2009, 2011a).

Here, in unstimulated and superstimulated heifers, we tested the hypothesis that follicular aspiration before ovulation interferes with the subsequent formation and function of the $\mathrm{CL}$, leading in turn to impaired endometrial receptivity and conceptus development. Following aspiration or ovulation, $\mathrm{CL}$ development was assessed by daily ultrasonography, and CL function was assessed in terms of the capacity to produce $\mathrm{P}_{4}$ and the expression of genes involved in steroidogenesis in luteal tissue. The capacity of the uterine environment to support conceptus development was assessed following transfer and recovery of in vitro-produced embryos.

\section{Results}

\section{Follicle diameter at aspiration}

In the unstimulated heifers, one follicle was aspirated per heifer. In the superstimulated group, a mean of $19.2 \pm 1.8$ follicles were aspirated per heifer (range per heifer, $14-24$ follicles aspirated). Mean ( \pm s.E.M.) follicle diameter at aspiration was $14.56 \pm 0.63 \mathrm{~mm}(n=9)$ in unstimulated and $8.21 \pm 0.13(n=96)$ in superstimulated heifers $(P<0.05)$.

\section{CL development}

The dimensions of the $\mathrm{CL}$ measured using ultrasound scanning between days 3 and 13 in unstimulated heifers are shown in Fig. 1. Follicular aspiration just before the expected time of ovulation leads to a significant reduction $(P<0.05)$ in $\mathrm{CL}$ diameter (from day 6 onwards), total $\mathrm{CL}$ area (from day 6 onwards) and area of luteal tissue (i.e. CL area corrected for the presence of a cavity, if any, from day 5 onwards; Fig. 1). This difference was also apparent at slaughter on day 14 in terms of $\mathrm{CL}$ weight, diameter and area (Table 1; Fig. 2).

$\mathrm{CL}$ characteristics in the superstimulated heifers undergoing follicle aspiration before the expected time
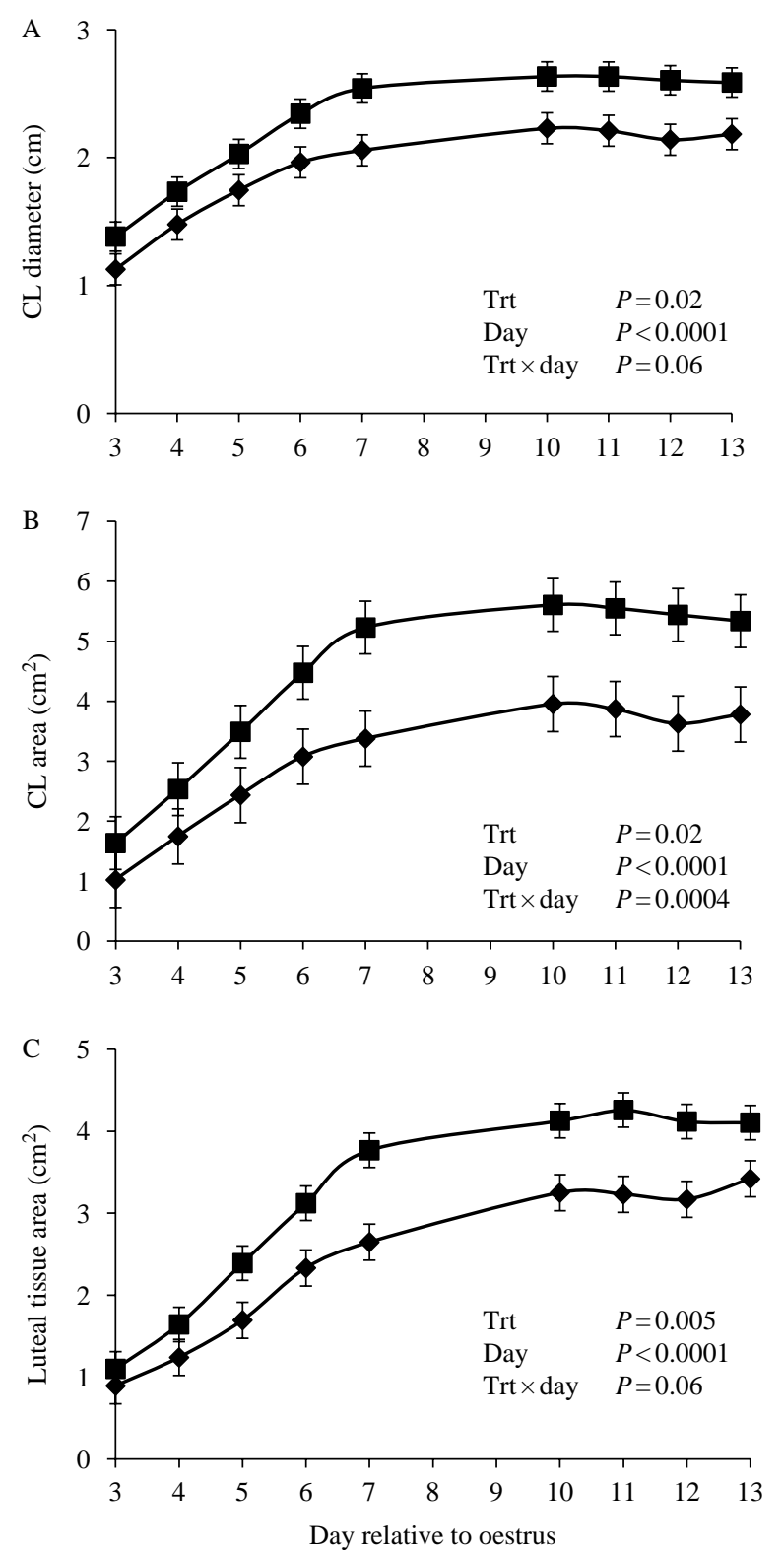

Figure 1 Maximum corpus luteum (CL) diameter $(A)$, total $C L$ area $(B)$ and total area of luteal tissue (i.e. minus any cavity area; $C$ ) in unstimulated (i.e. single-ovulating) heifers undergoing ovulation (filled square, $n=10$ ) or undergoing follicle aspiration just before expected time of ovulation (filled diamond, $n=10$ ). Significant difference $(P<0.05)$ was present for diameter $(A)$ and total $C L$ area $(B)$ from day 6 onwards and for total area of luteal tissue $(C)$ from day 5 onwards. 
Table 1 Corpus luteum $(\mathrm{CL})$ characteristics at slaughter on day 14 in unstimulated (i.e. single-ovulating) heifers undergoing ovulation $(n=9)$ or follicle aspiration just before expected time of ovulation $(n=9)$.

\begin{tabular}{|c|c|c|c|c|}
\hline Treatment & $\begin{array}{l}\text { CL weight } \\
\text { (g) })^{\text {d }}\end{array}$ & $\begin{array}{l}\mathrm{CL} \text { diameter } \\
(\mathbf{c m})^{\mathrm{d}}\end{array}$ & $\begin{array}{l}\text { CL area } \\
\left(\mathrm{cm}^{2}\right)^{d}\end{array}$ & $\begin{array}{l}\text { Luteal tissue } \\
\text { area }\left(\mathbf{c m}^{2}\right)^{\mathrm{d}, a}\end{array}$ \\
\hline Ovulation $^{\text {b }}$ & $8.42 \pm 1.24$ & $2.73 \pm 0.12$ & $59.42 \pm 4.69$ & $47.20 \pm 4.89$ \\
\hline & $4.16 \pm 1.24$ & $1.99 \pm 0.12$ & $32.19 \pm 4.69$ & $27.75 \pm 4.89$ \\
\hline$P$ value & 0.02 & 0.006 & 0.0008 & 0.01 \\
\hline
\end{tabular}

FA, Follicle aspiration.

${ }^{a}$ Corrected for the presence of a cavity. ${ }^{b}$ Excluding one heifer due to the presence of a double ovulation. ${ }^{C}$ Excluding one heifer as ovary with $\mathrm{CL}$ not recovered at abattoir. ${ }^{\mathrm{d}}$ Data represented as mean \pm s.E.M.

of ovulation or undergoing natural ovulation were recorded after slaughter on day 14 and are presented in Table 2. The mean number of $\mathrm{CL}$ differed between groups $(23.0 \pm 8.13$ vs $14.4 \pm 2.84$ for ovulated and aspirated respectively), a reflection of variation in animal response to superstimulatory treatments. Follicular aspiration just before the expected time of ovulation leads to a significant reduction $(P<0.05)$ in mean $\mathrm{CL}$ weight, diameter and area compared with controls.

\section{Circulating $\boldsymbol{P}_{\mathbf{4}}$ concentrations}

Circulating concentrations of $\mathrm{P}_{4}$ for unstimulated and superstimulated animals are presented in Fig. 3. In both groups, follicle aspiration just before ovulation reduced serum $\mathrm{P}_{4}$ concentration. Similarly, in both groups, circulating $\mathrm{P}_{4}$ concentrations were lower at all time points from days 3 to 14 but were only statistically significant from day 7 onwards $(P<0.05)$.

\section{Embryo recovery and development}

Significantly fewer embryos were recovered from unstimulated heifers undergoing ovulation (39/72, $54.2 \%$ ) than those undergoing follicle aspiration (56/88, 63.6\%). Follicle aspiration before ovulation leads to a significant reduction in conceptus length $(P=0.002)$ and area $(P=0.01)$ on day 14 compared with controls (Table 3 ). In the superstimulated group, there was no difference in embryo recovery rate between those undergoing ovulation $(15 / 20,75 \%)$ or follicle aspiration (20/25, 80\%). Furthermore, conceptus dimensions were not affected by treatment (Table 4 ).

\section{$C L$ gene expression analysis}

Luteal expression of CYP11A1, HSD3B1 and STAR was not affected by follicle aspiration before ovulation or by superstimulation treatment. Follicle aspiration leads to a reduction in expression of $L H C G R$ in luteal tissue from unstimulated heifers compared with those in which the $\mathrm{CL}$ formed after ovulation $(P<0.05)$.
Superstimulation significantly reduced the expression of STAR in luteal tissue, irrespective of follicle aspiration or ovulation (Fig. 4).

\section{Discussion}

The main findings from this study are that follicle aspiration before ovulation results in a reduction in $\mathrm{CL}$ size and $\mathrm{P}_{4}$ output and, in unstimulated animals, decreased expression of $L H C G R$ in luteal tissue and a compromised uterine capacity to support conceptus elongation. These findings are relevant not only for cattle, where oestrous synchronisation programmes involving GNRH-induced ovulation may lead to the ovulation of a premature follicle, a smaller $\mathrm{CL}$ with a lower $\mathrm{P}_{4}$ output and thereby a compromised uterine environment, but also for human infertility treatment given the high reported frequency of luteal dysfunction following ovarian stimulation and follicle aspiration as evidenced by the fact that $\mathrm{P}_{4}$ supplementation postembryo transfer is common.

Follicular diameter at ovulation and the duration of proestrus have been identified as sources of variation in conception rate in cattle (Lamb et al. 2001, Peters \& Pursley 2003, Perry et al. 2005, Mussard et al. 2007). $\mathrm{P}_{4}$ concentrations and $\mathrm{CL}$ cross-sectional area are reduced in animals induced to ovulate prematurely. For example, Mussard et al. (2007) demonstrated that premature ovulation of a dominant follicle with GNRH reduced the size of the ovulatory follicle, reduced fertility and decreased subsequent luteal function. Furthermore, granulosa cells make a substantial contribution to the $\mathrm{P}_{4}$ output of the $\mathrm{CL}$ and aspiration of the preovulatory follicle inevitably involves removal of follicular fluid and a variable number of granulosa cells. This process has been implicated in the subsequent compromised formation and function of the $\mathrm{CL}$ leading to impaired endometrial receptivity (termed luteal insufficiency in the human literature). CLs formed after removal of a large number of granulosa cells from the preovulatory follicle in cattle have a limited capacity to produce $\mathrm{P}_{4}$. Milvae et al. (1991) reported that aspiration of follicular fluid and granulosa cells from bovine preovulatory follicles resulted in a reduction in circulating $\mathrm{P}_{4}$ in the subsequent luteal phase. Interestingly, removal and return of follicular fluid resulted in similar

Table 2 Corpus luteum (CL) characteristics at slaughter on day 14 in superstimulated heifers undergoing ovulation $(n=4)$ or follicle aspiration just before expected time of ovulation $(n=5)$.

\begin{tabular}{|c|c|c|c|c|}
\hline Treatment & $\begin{array}{l}\text { CL number } \\
\text { per heifer }^{\mathrm{a}}\end{array}$ & $\begin{array}{l}\mathrm{CL} \text { weight } \\
(\mathrm{g})^{\mathrm{a}}\end{array}$ & $\begin{array}{c}\text { CL diameter } \\
(\mathbf{c m})^{\mathrm{a}}\end{array}$ & $\begin{array}{c}\text { CL area } \\
\left(\mathrm{cm}^{2}\right)^{\mathrm{a}}\end{array}$ \\
\hline Ovulation & $23.0 \pm 8.13$ & $1.95 \pm 0.10$ & $1.51 \pm 0.041$ & $18.73 \pm 0.97$ \\
\hline FA & $14.4 \pm 2.84$ & $1.16 \pm 0.12$ & $1.26 \pm 0.048$ & $13.69 \pm 1.13$ \\
\hline$P$ value & $<0.05$ & $<\overline{0.0001}$ & 0.0005 & $0 . \overline{003}$ \\
\hline
\end{tabular}

FA, Follicle aspiration.

${ }^{\text {a }}$ Data represented as mean \pm S.E.M. 

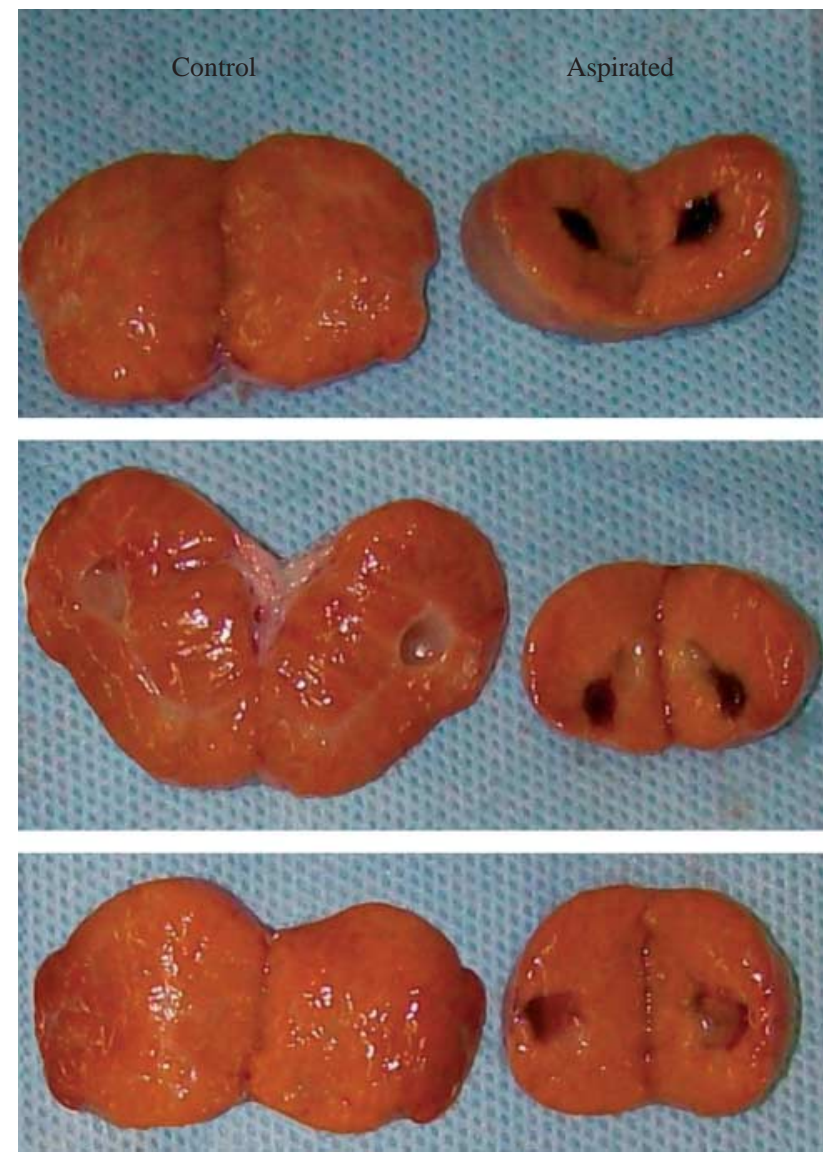

Figure 2 Representative images of dissected corpora lutea $(\mathrm{CL})$ from unstimulated (i.e. single-ovulating) heifers undergoing ovulation (left) or undergoing follicle aspiration just before expected time of ovulation (right). Note the larger CL following ovulation and the presence of a blood clot in CLs formed after follicular aspiration.

$\mathrm{P}_{4}$ concentrations to controls. In humans and nonhuman primates, luteal dysfunction after follicle aspiration of preovulatory follicles and failures in human IVF have been related to lower maternal $\mathrm{P}_{4}$ (Garcia et al. 1981, Kreitmann et al. 1981, Vargyas et al. 1986).

Follicle diameter at the time of aspiration was smaller in superstimulated heifers compared with unstimulated heifers. This is consistent with the fact that co-dominant follicles (or multiple dominant follicles) do not grow as large as singletons (Adams et al. 1993). In both stimulated and unstimulated heifers, CL weight, diameter and area were significantly lower following follicle aspiration compared with when ovulation took place. However, consistent with the follicle diameter data, CL weight, diameter and area were lower following superstimulation compared with unstimulated heifers. Early luteinisation of preovulatory follicles after follicular aspiration in mares has been described (Hinrichs et al. 1991). It was suggested that the diameter at aspiration may influence the subsequent $\mathrm{CL}$ formation. Mozzaquatro et al. (2011) reported that a functional CL can be induced in mares using follicular aspiration but that a follicular diameter of at least $35 \mathrm{~mm}$ is necessary to reach $\mathrm{P}_{4}$ serum concentration comparable with that of a $\mathrm{CL}$ produced by natural ovulation. Follicular aspiration resulted in a slower increase in serum $\mathrm{P}_{4}$ concentrations compared with controls. In cattle, Hayashi et al. (2006) aspirated follicles before or after a GNRH-induced LH surge and observed that $\mathrm{CL}$ formation only occurred when aspiration took place after the LH surge indicating that the LH surge rather than follicle rupture is essential for $\mathrm{CL}$ formation. In the post-LH group, plasma $\mathrm{P}_{4}$ concentration, $\mathrm{CL}$ volume and luteal blood flow were not different from the intact follicle group, which underwent ovulation.

Regardless of species, a dialogue between the developing conceptus and maternal uterus must be established during the peri-implantation period. The uterus must provide a microenvironment that supports growth and development of the conceptus and is receptive to implantation. During the same period, the conceptus must provide pregnancy recognition signalling to sustain the functional life of CL for production of $\mathrm{P}_{4}$, which is essential for implantation and placentation. Indeed, in cattle, it has been shown that compromised
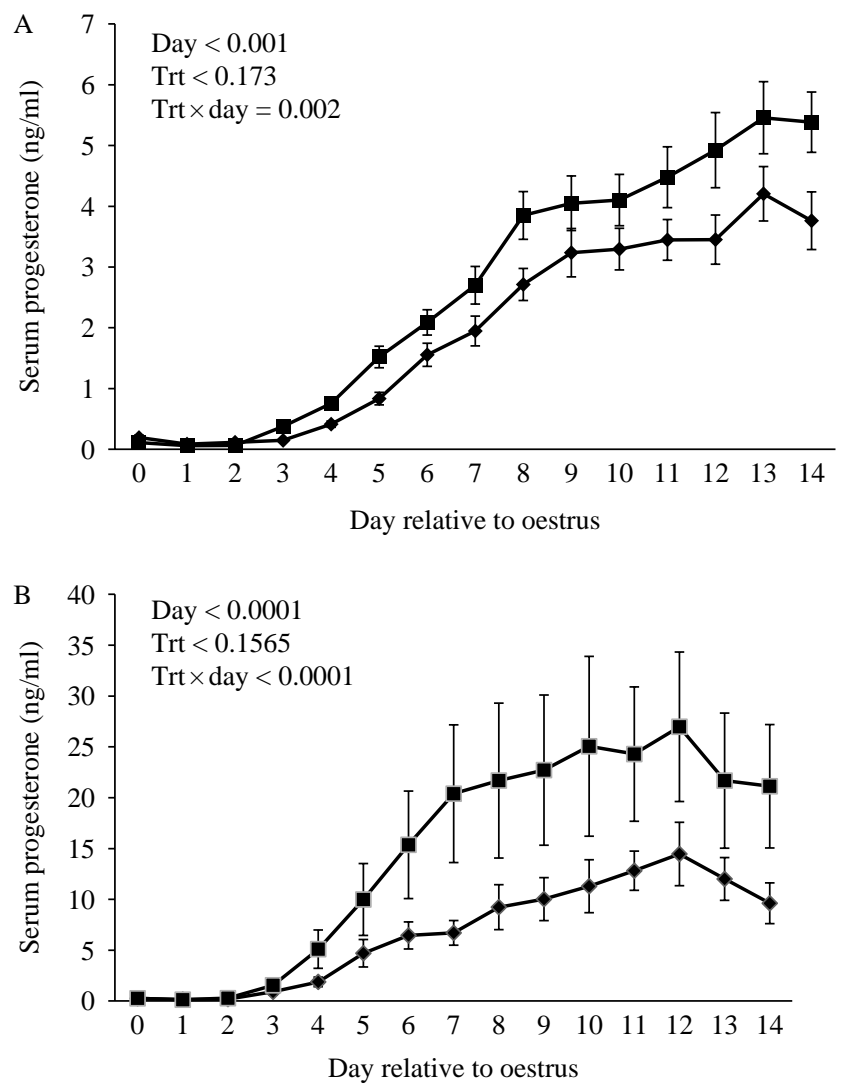

Figure 3 Serum progesterone concentrations in (A) unstimulated (i.e. single-ovulating, $n=20$ ) and (B) superstimulated $(n=9)$ heifers undergoing ovulation (filled square) or undergoing follicle aspiration (filled diamond) just before the expected time of ovulation. In both groups, $\mathrm{P}_{4}$ concentrations were lower at all time points from days 3-14 but were only statistically significant from day 7 onwards $(P<0.05)$. 
Table 3 Conceptus dimensions following transfer of day 7 bovine blastocysts to unstimulated (i.e. single-ovulating) heifers undergoing ovulation $(n=9)$ or follicle aspiration just before expected time of ovulation $(n=10)$ and recovery at slaughter on day 14 .

\begin{tabular}{|c|c|c|c|c|}
\hline \multirow[b]{2}{*}{ Treatment } & \multirow{2}{*}{$\begin{array}{c}\text { Number } \\
\text { of embryos } \\
\text { recovered/ } \\
\text { transferred (\%) }\end{array}$} & \multicolumn{3}{|c|}{ Conceptus dimensions ${ }^{\mathrm{a}}$} \\
\hline & & $\begin{array}{c}\text { Length } \\
(\mathrm{mm})\end{array}$ & $\begin{array}{l}\text { Width } \\
(\mathbf{m m})\end{array}$ & $\begin{array}{c}\text { Area } \\
\left(\mathrm{mm}^{2}\right)\end{array}$ \\
\hline Ovulation & 39/72 (54.2) & $4.06 \pm 0.51$ & $0.98 \pm 0.08$ & $4.71 \pm 0.66$ \\
\hline & $56 / 88(63.6)$ & $1.99 \pm 0.42$ & $1.03 \pm 0.07$ & $2.41 \pm 0.55$ \\
\hline$P$ value & $<0.05$ & 0.002 & 0.61 & 0.01 \\
\hline
\end{tabular}

FA, Follicle aspiration.

${ }^{\mathrm{a}}$ Data represented as mean \pm s.E.M.

embryos that fail to elicit a normal response from the endometrium are less likely to survive (Heyman et al. 2002, Bauersachs et al. 2009, Mansouri-Attia et al. 2009). Post-hatching conceptus elongation in ruminants is a maternally driven process. Evidence for this comes from the fact that post-hatching conceptus elongation does not occur in vitro (Brandao et al. 2004, Vejlsted et al. 2006) and fails to occur in vivo in the absence of uterine glands (Gray et al. 2002, Spencer \& Gray 2006). $P_{4}$ is central to this process. Elevated $P_{4}$ in the first week post-conception advances the normal temporal changes that occur in the uterine endometrial transcriptome (Forde et al. 2009) and this, in turn, leads to an advancement in conceptus elongation in cattle (Carter et al. 2008, Clemente et al. 2009). Furthermore, a delay in the post-ovulatory rise in $\mathrm{P}_{4}$ is associated with retarded conceptus development (Forde et al. 2011a). Similarly, in women, following ovulation, $\mathrm{P}_{4}$, produced by the $\mathrm{CL}$, induces secretory transformations of the endometrium (Bourgain et al. 1990) and allows endometrial receptivity and embryo implantation (Kolibianakis \& Devroey 2002). In the case of conception, trophoblastderived human chorionic gonadotrophin (hCG) prevents $\mathrm{CL}$ regression and amplifies steroid secretion that consequently decidualises the endometrial stroma and supports early embryonic development.

The reasons for abnormal luteal function in women after ovarian stimulation for IVF are not clear but proposed mechanisms (Beckers et al. 2003) include the following: i) continued downregulation due to preceding follicular phase GNRH agonist coadministration may retard pituitary recovery, ii) induction of multiple follicle development could influence the duration of the luteal phase, iii) removal of large quantities of granulosa cells may diminish $\mathrm{CL}$ capacity to produce $\mathrm{P}_{4}$ (Garcia et al. 1981, Vargyas et al. 1986) and iv) supraphysiological concentrations of steroids associated with multiple corpora lutea could inhibit LH release due to negative feedback (Fauser \& Devroey 2003). Exogenous supplemental $\mathrm{P}_{4}$ is a common practice in IVF-stimulated cycles because of associated luteal phase defects (Kolibianakis et al. 2003). Although the benefit of $P_{4}$ administration as luteal phase support has been well documented in IVF (Fatemi et al. 2007), a question surrounds the optimum time for its discontinuation (Nyboe Andersen et al. 2002, Griesinger 2011, Kyrou et al. 2011).

Aspiration of the preovulatory dominant follicle just before ovulation in unstimulated heifers was associated with a compromised $\mathrm{CL}$ in terms of size and $\mathrm{P}_{4}$ output. Consistent with our previous observations, reduction in circulating $\mathrm{P}_{4}$ leads to a reduction in conceptus length and area on day 14 in unstimulated (i.e. single-ovulating) heifers. This is important given the linear association between conceptus size and interferon- $\tau$ production (Rizos et al. 2012). Interestingly, while aspiration of multiple dominant follicles before the expected time of ovulation in superstimulated heifers was also associated with a compromised $\mathrm{CL}$ in terms of size and $\mathrm{P}_{4}$ output compared with those that ovulated, there was no deleterious effect on conceptus size on day 14. The lack of an effect on conceptus growth is probably due to the fact that the reduced concentrations of $\mathrm{P}_{4}$ in this group were still high, being greater than concentrations in unstimulated animals undergoing ovulation (see Fig. 3).

Alterations in differentiation of the CL were examined by measuring abundances of genes involved in the $\mathrm{LH}$-induced signalling cascades and steroidogenesis in the CL (LHCGR, STAR, CYP11A1 and HSD3B1). LH is the primary gonadotropin that regulates differentiation and function of the $\mathrm{CL}$ including STAR and $\mathrm{P}_{4}$ production (Stocco et al. 2007). STAR is the mitochondrial enzyme involved in shuttling cholesterol into the inner mitochondrial membrane, which in turn is converted by the side-chain cleavage enzyme system into pregnenolone (Stocco \& Clark 1996); as such, STAR is the rate-limiting step in steroidogenesis in many tissues including the CL (Stocco \& Clark 1996). Luteal expression of CYP11A1 and HSD3B1 was not affected by follicle aspiration before ovulation or by superstimulation treatment. Follicle aspiration leads to a reduction in the expression of $L H C G R$ in luteal tissue from unstimulated heifers compared with those in which the $\mathrm{CL}$ formed after ovulation; this effect was not observed after superstimulation. Superstimulation significantly reduced the

Table 4 Conceptus dimensions following transfer of day 7 bovine blastocysts to superstimulated heifers undergoing ovulation $(n=4)$ or follicle aspiration just before expected time of ovulation $(n=5)$ and recovery at slaughter on day 14 .

\begin{tabular}{lcccc}
\hline & $\begin{array}{c}\text { Number of } \\
\text { embryos } \\
\text { recovered/ }\end{array}$ & \multicolumn{3}{c}{ Conceptus dimensions $^{\mathrm{a}}$} \\
\cline { 3 - 5 } Treatment & $\begin{array}{c}\text { Length } \\
\text { transferred }(\%)\end{array}$ & $\begin{array}{c}\text { Width } \\
(\mathbf{m m})\end{array}$ & $\begin{array}{c}\text { Area } \\
(\mathbf{m m})\end{array}$ & $\left.\mathbf{m m}^{\mathbf{2}}\right)$ \\
\hline Ovulation & $15 / 20(75.0)$ & $3.51 \pm 0.92$ & $1.40 \pm 0.13$ & $4.84 \pm 1.63$ \\
FA & $20 / 25(80.0)$ & $3.44 \pm 0.80$ & $1.17 \pm 0.11$ & $5.41 \pm 1.46$ \\
$P$ value & 0.73 & 0.96 & 0.21 & 0.89 \\
\hline
\end{tabular}

FA, Follicle aspiration.

${ }^{\text {a }}$ Data represented as mean \pm S.E.M. 


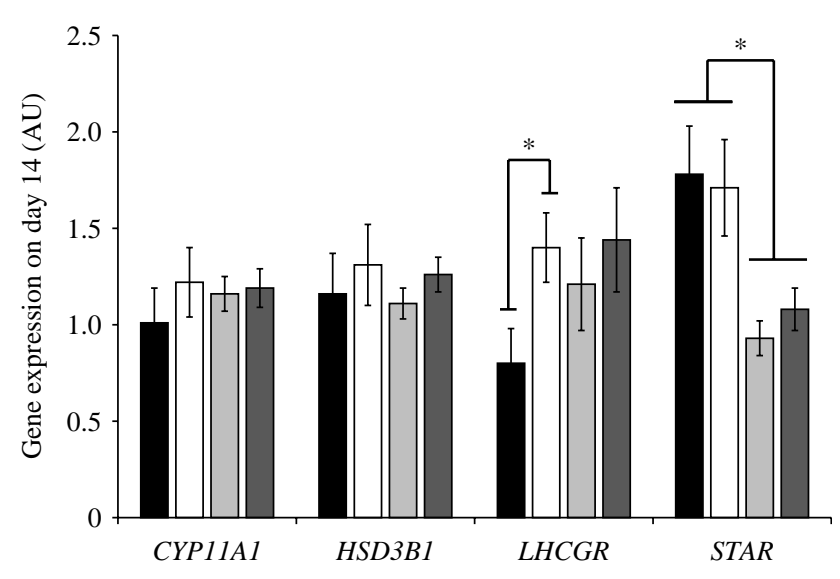

Figure 4 QRT-PCR analysis of the expression of four candidate genes (mean CNRQ values \pm s.E.M.) in the CL of unstimulated and superstimulated heifers formed following follicle aspiration just before ovulation or following ovulation. Black bars, unstimulated aspirated; white bars, unstimulated ovulated; light grey bars, superstimulated heifers aspirated; dark grey bars, superstimulated ovulated. An asterisk $(*)$ indicates a significant difference in expression $(P<0.05)$. CYP11A1, cytochrome P450, family 11 , subfamily A, polypeptide 1 ; HSD3B1, hydroxy- $\Delta-5$-steroid dehydrogenase, $3 \beta$ - and steroid $\Delta$-isomerase 1 ; $L H G C R, \mathrm{LH} /$ choriogonadotropin receptor; STAR, steroidogenic acute regulatory protein.

expression of STAR mRNA in luteal tissue, irrespective of whether follicle aspiration or ovulation took place. High variation in ovarian reserves is associated with alterations in $\mathrm{CL}$ differentiation and function. Jimenez-Krassel et al. (2009) found that $\mathrm{P}_{4}$ concentrations were lower during oestrous cycles for animals with lower vs higher antral follicle count. Animals with low antral follicle count also had a decreased capacity of luteal and granulosa cells to produce $\mathrm{P}_{4}$, reduced amount of STAR and $\mathrm{mRNA}$ for STAR and $\mathrm{LH}$ receptor in the CL.

In conclusion, aspiration of the preovulatory follicle resulted in a reduction in $\mathrm{CL}$ size and $\mathrm{P}_{4}$ output in unstimulated and superstimulated cattle. In unstimulated animals, this was associated with a reduction in the capacity of the uterine environment to support conceptus elongation, while in superstimulated animals, the reduced $\mathrm{P}_{4}$ concentrations were apparently still sufficient to drive this process. These data have relevance not only for oestrous synchronisation programs in cattle involving GNRH-induced ovulation but also for assisted human reproduction where oocytes derived from women undergoing $\mathrm{COH}$ are recovered by transvaginal preovulatory follicle aspiration and routinely replaced in the uterus of the same women during the same cycle, in contrast to the situation in cattle, where transfer to unstimulated surrogate recipients is the norm. The negative effect of ovarian stimulation on the uterine environment is highlighted by the fact that high-quality embryos transferred into unstimulated women involved as embryo recipients in a surrogacy procedure have a higher likelihood of implanting than if they are transferred back into the donors (Check et al. 1992, Stafford-Bell \& Copeland 2001).

\section{Materials and Methods}

\section{Animals and treatments}

All experimental procedures involving animals were licensed by the Department of Health and Children, Ireland. Protocols were in accord with the Cruelty to Animals Act (Ireland 1897) and the European Community Directive 86/609/EC and were sanctioned by the Institutional Animal Research Ethics Committee.

The experimental design is illustrated in Fig. 5. All animals were housed indoors on slats for the duration of the experiment and were fed a diet consisting of grass and maize silage supplemented with a standard beef ration. The oestrous cycles of crossbred beef heifers, predominantly Charolais and Limousin cross (mean age $23.7 \pm 0.69$ months, mean weight 584.98 $\pm 8.85 \mathrm{~kg}$ ), were synchronised using an 8-day Controlled Internal Drug Release device (CIDR $1.9 \mathrm{~g}$, Pfizer, Sandwich, Kent, UK) with administration of a prostaglandin F2 $\alpha$ (PGF2 $\alpha$ ) analogue (2 $\mathrm{ml}$ Estrumate; Schering-Plough Animal Health, Hertfordshire, UK, equivalent to $0.5 \mathrm{mg}$ cloprostenol) given on the day before CIDR removal. Heifers were checked for signs of oestrus four times per day commencing $30 \mathrm{~h}$ after CIDR withdrawal and only those recorded in standing oestrus (day $0 ; n=29$ ) were used. Heifers were randomly assigned to be treated as unstimulated (i.e. single-ovulating, $n=20$ ) or

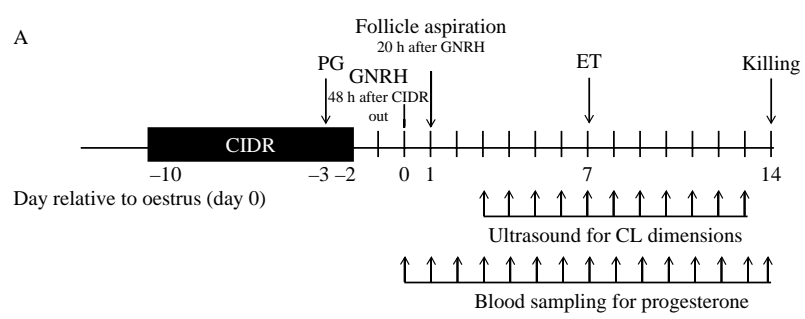

B

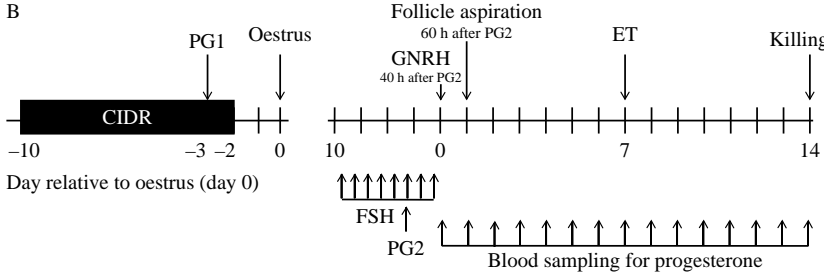

Figure 5 Experimental design. (A) Unstimulated (i.e. single-ovulating) heifers $(n=20)$ were synchronised with an 8-day progesterone insert with prostaglandin (PG) administered the day before device removal. All heifers received GNRH $48 \mathrm{~h}$ after device removal and half underwent follicle aspiration $20 \mathrm{~h}$ later; the remainder underwent ovulation. Corpus luteum (CL) dimensions were assessed by ultrasound scanning from days 3 to 13 . (B) Superstimulated heifers $(n=9)$ were administered eight injections of FSH starting on day 10 after a synchronised oestrus. Prostaglandin (PG2) was administered with the sixth FSH injection. All heifers received GNRH $40 \mathrm{~h}$ after PG2 and approximately half $(n=5)$ underwent follicle aspiration $20 \mathrm{~h}$ later; the remainder underwent ovulation. Blood samples were taken from days 0 to 14 to measure serum progesterone concentration. 
superstimulated $(n=9)$. As fewer animals were deemed necessary in the superstimulated group, once the desired number (originally 10, but one animal was lost) was reached, the remaining heifers were assigned to the unstimulated group. Within each group, approximately half of the animals underwent follicle aspiration just before the expected time of ovulation while the remainder were allowed to ovulate naturally. Follicle aspiration (removal of entire follicular contents) was achieved using an ultrasound scanner (SSD-500; Aloka, Tokyo, Japan) and a 5.0 MHz convex array transducer (UST-974-5; Aloka) attached to a 17 G $\times 540 \mathrm{~mm}$ stainless steel needle guide. The aspiration pressure was $\sim 50 \mathrm{~mm} \mathrm{Hg}$.

\section{Unstimulated heifers}

Heifers received a GNRH agonist $(2.5 \mathrm{ml}$ Receptal, Intervet Ireland Ltd., Dublin, Ireland, equivalent to $0.01 \mathrm{mg}$ buserelin) $48 \mathrm{~h}$ after CIDR removal to induce an LH surge. This treatment has been shown to induce a preovulatory $\mathrm{LH}$ surge $2 \pm 3 \mathrm{~h}$ after injection (Bordignon et al. 1997, van de Leemput et al. 1999). Half of the animals underwent follicle aspiration $20 \mathrm{~h}$ later while the remainder underwent natural ovulation. The diameter of the dominant preovulatory follicle at puncture was measured using an optical calliper.

\section{Superstimulated heifers}

Procedures for superstimulation and follicle aspiration were as described by Rizos et al. (2002). Beginning on day 10 of a synchronised oestrous cycle, heifers were superstimulated with a total of $455 \mathrm{IU}$ FSH (13 ml Folltropin; Bioniche, Inverin, Galway, Ireland) given as twice daily i.m. injections over 4 days on a decreasing dose schedule. Luteolysis was induced with $2 \mathrm{ml}$ Estrumate (PGF2 $\alpha$ ) given on day 12 with the sixth injection of $\mathrm{FSH}$. All heifers received $2.5 \mathrm{ml}$ Receptal $(\mathrm{GNRH})$ at $40 \mathrm{~h}$ after PG, the expected time of the LH surge (Callesen et al. 1986) and follicle aspiration was performed $\sim 20 \mathrm{~h}$ later (i.e. $60 \mathrm{~h}$ after PG). As above, the diameter of all punctured preovulatory follicles was measured using an optical calliper.

\section{In vitro embryo production}

Unless otherwise stated, all chemicals were purchased from Sigma Chemical Company. The techniques for producing embryos in vitro have been described in detail previously (Rizos et al. 2002). Immature cumulus-oocyte complexes (COCs) were obtained by aspirating follicles from the ovaries of heifers and cows collected at killing. COCs were matured for $24 \mathrm{~h}$ in TCM-199 supplemented with $10 \%$ (v/v) FCS and $10 \mathrm{ng} /$ $\mathrm{ml}$ epidermal growth factor at $39{ }^{\circ} \mathrm{C}$ under an atmosphere of $5 \% \mathrm{CO}_{2}$ in air with maximum humidity. For IVF, matured COCs were inseminated with frozen-thawed Percoll-separated bull sperm at a concentration of $1 \times 10^{6} \mathrm{spermatozoa} / \mathrm{ml}$. Gametes were co-incubated at $39{ }^{\circ} \mathrm{C}$ under an atmosphere of $5 \% \mathrm{CO}_{2}$ in air with maximum humidity. Semen from the same bull was used for all experiments. At $\sim 20 \mathrm{~h}$ post-insemination (hpi), presumptive zygotes were denuded and cultured in groups of 50 in $500 \mu \mathrm{l}$ synthetic oviduct fluid supplemented with $5 \%$ FCS. Cleavage rate was recorded at $48 \mathrm{hpi}$ and blastocyst development recorded at day 7 pi.

\section{CL ultrasonography}

In order to assess the effect of follicle puncture on $\mathrm{CL}$ development, daily transrectal ultrasonography commenced on day 3 (oestrus=day 0 ) in the unstimulated heifers. This procedure was not carried out in the superstimulated groups because of the difficulty of correctly scanning the multiple CLs present. Ultrasound examination of the ovaries was performed using a Volusoni portable ultrasound system (GE Healthcare, Vienna, Austria) equipped with an RNA $12 \mathrm{~L}$ linear probe emitting a frequency of $12 \mathrm{MHz}$. All ultrasound examinations were carried out by the same operator. Upon visualisation of the ovary, three consecutive images of the $\mathrm{CL}$ were taken. Maximum $\mathrm{CL}$ diameter and diameter of a $\mathrm{CL}$ cavity, where present, were recorded. Images were saved and stored on the ultrasound system for later analysis. The area

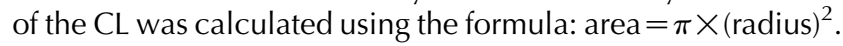
For unstimulated heifers, the area of a cavity, if present, was subtracted from the total $\mathrm{CL}$ area to get the total luteal tissue area.

\section{$P_{4}$ measurement}

Blood samples were taken daily by jugular venipuncture. Following collection, blood samples were refrigerated $\left(4{ }^{\circ} \mathrm{C}\right)$ for $12-24 \mathrm{~h}$ before being centrifuged at $1500 \mathrm{~g}$ at $4{ }^{\circ} \mathrm{C}$ for $20 \mathrm{~min}$. Serum was separated and stored at $-20{ }^{\circ} \mathrm{C}$ until analysis to determine $\mathrm{P}_{4}$ concentration by solid-phase RIA using a Coat-A-Count $\mathrm{P}_{4}$ kit (Siemens Medical Solutions Diagnostics, Los Angeles, CA, USA) as described previously (Forde et al. 2011b). The sensitivity of the assay was $0.03 \mathrm{ng} /$ $\mathrm{ml}$. The inter- and intra-assay coefficients of variation for the were 13.9 and $14.6 \%, 8.3$ and $6.9 \%$ and 9.4 and $4.5 \%$ for low-, medium- and high-quality control serum pools respectively.

\section{Embryo transfer and recovery}

In order to test the ability of the uterus to support embryo development and conceptus elongation, day 7 in vitroproduced blastocysts were transferred to the uteri of synchronised recipients (five to ten blastocysts per recipient) as described previously (Clemente et al. 2009, Forde et al. $2011 b)$. All recipients were killed on day 14 to assess conceptus development. Following killing, the reproductive tract was removed, sealed in a plastic bag and placed in a sealed polystyrene box for transportation to the laboratory (within $60 \mathrm{~min}$ ). After removal of the ovaries and the oviducts, the uterine horns were trimmed free of excess tissue before being flushed with $40 \mathrm{ml}$ PBS. On recovery, the dimensions (length, width and area) of each conceptus were recorded.

\section{CL processing}

In the unstimulated group, at killing, the CL was dissected free from the ovary, weighed and the diameter was recorded. The $\mathrm{CL}$ was then cut into half and the diameter of any cavity present was also recorded. The area of the CL was calculated 


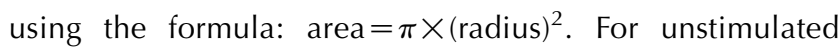
heifers, the area of a cavity, if present, was subtracted from the total $\mathrm{CL}$ area to get the total luteal tissue area. A portion of the $\mathrm{CL}$ was snap frozen for subsequent gene expression analysis. In the case of the superstimulated heifers, the total number of CLs present on each ovary was recorded. The CLs were then dissected free from the ovaries, weighed and the diameter was recorded. Owing to the large number of CLs present in the superstimulated heifers, which increased dissection and processing time, cavities were not recorded to avoid tissue degradation before samples were snap frozen for further analysis. Thus, only $\mathrm{CL}$ diameter and $\mathrm{CL}$ area are presented for this group. A portion of up to five randomly selected CLs per ovary per heifer was snap frozen for gene expression analysis.

\section{mRNA analysis}

Total RNA was isolated from $\sim 30 \mathrm{mg}$ CL tissue in the singleovulating group and from a random selection of five CLs from each ovary of the superstimulated group, using Trizol reagent as per manufacturer's instructions (Invitrogen). An on-column DNase treatment and clean up was performed and quality and quantity of RNA were determined using the Agilent Bioanalyzer (Agilent Technologies, Santa Clara, CA, USA) and the NanoDrop 1000 (Thermo Fischer Scientific, Inc., Wilmington, DE, USA) respectively. Following cDNA synthesis of $500 \mathrm{ng}$ total RNA (high-capacity reverse transcriptase kit; Applied Biosystems, Carlsbad, CA, USA), the expression of selected genes in the $C L$ tissue was analysed by quantitative real-time PCR using the primer concentrations listed in Table 5. Primers were designed using primer-BLAST Software (www.ncbi.nlm. nih.gov/tools/primer-blast/). Each QRT-PCR reaction was carried out on the 7300 Real-Time PCR System (Applied Biosystems) in a final reaction volume of $20 \mu \mathrm{l}$. Cycling conditions were as follows: $2 \mathrm{~min}$ at $50{ }^{\circ} \mathrm{C}, 10 \mathrm{~min}$ at $95^{\circ} \mathrm{C}$ and 40 cycles of $95^{\circ} \mathrm{C}$ for $15 \mathrm{~s}$ and $60^{\circ} \mathrm{C}$ for $1 \mathrm{~min}$ and were carried out with the inclusion of a dissociation curve to ensure specificity of amplification. A standard curve was included for each gene of interest including the normaliser genes to obtain primer efficiencies. All raw cycle threshold values were then

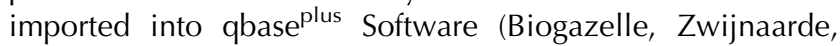

Belgium) where data were calibrated, normalised and expression values for each gene were determined in arbitrary units (calibrated normalized relative quantities values).

\section{Statistical analysis}

Data were checked for normality and homogeneity of variance using histograms, qplots and formal statistical tests in the UNIVARIATE procedure (version 9.1.3; SAS Institute, Cary, NC, USA, 2006). Data that were not normally distributed were transformed by raising the variable to the power of lambda. The appropriate lambda value was obtained by conducting a Box-Cox transformation analysis using the TRANSREG procedure of SAS. The transformed data were used to calculate $P$ values. The corresponding least squares means and S.E.M. of the non-transformed data are presented in the results for clarity. Variables having more than one observation such as the $\mathrm{P}_{4}$ concentrations and ovarian ultrasonic measures were analysed for the unstimulated and superstimulated groups using a repeated measures analysis with the MIXED procedure of SAS. Fixed effects included experimental treatment (ovulate naturally or follicle aspiration before ovulation), day and their interaction. The interaction term if not statistically significant $(P>0.10)$ was subsequently excluded from the final model. Animal within treatment was included as a random effect in the model with the most appropriate covariance structure between records within animal determined by minimising the Akaike Information Criterion (AIC). Models were run under compound symmetry, unstructured, autoregressive or Toeplitz variance-covariance structures. Embryo-related data for the unstimulated and superstimulated groups were analysed using the PROC MIXED procedure of SAS. The model had experimental treatment (ovulate naturally or follicle aspiration before ovulation) as a fixed effect and 'animal within treatment' was included as a random effect. Similarly, gene expression data for the unstimulated and superstimulated groups were analysed using the PROC MIXED procedure of SAS. The model had experimental treatment (ovulate naturally or follicle aspiration before ovulation) as a fixed effect. Differences between treatments were determined

Table 5 Gene symbol, name and accession number used to design forward and reverse primers used for qRT-PCR. All primers were used at a final concentration of $300 \mathrm{nM}$.

\begin{tabular}{|c|c|c|c|}
\hline Accession number & Entrez gene symbol & Gene name & Primer sequence \\
\hline NP_776614.1 & STAR & Steroidogenic acute regulatory protein & $\begin{array}{l}\text { F: CCTCAAGGACCAAACTCACC } \\
\text { R: GTGATTGGCAAAATCCACCT }\end{array}$ \\
\hline NM_174343 & HSD3B1 & $\begin{array}{l}\text { Hydroxy- } \Delta \text {-5-steroid dehydrogenase, } \\
3 \beta \text { - and steroid } \Delta \text {-isomerase } 1\end{array}$ & $\begin{array}{l}\text { F: CGCGAGAGACCATCATGAAC } \\
\text { R: CTATGGTGCTGGTGTGGATAAAG }\end{array}$ \\
\hline NM_174381.1 & LHCGR & LH/choriogonadotropin receptor & $\begin{array}{l}\text { F: GAAAGCACAGCAAGGAGACC } \\
\text { R: TGGAGTGTCTTGGGTAAGCA }\end{array}$ \\
\hline NM_176644 & CYP11A1 & $\begin{array}{l}\text { Cytochrome } \mathrm{P} 450 \text {, family } 11 \text {, subfamily } \\
\text { A, polypeptide } 1\end{array}$ & $\begin{array}{l}\text { F: AGGGGGTGTGAACACGACATCCA } \\
\text { R: GCCTGGCGTCGGGCATTCAG }\end{array}$ \\
\hline NM_174152 & $P P I B$ & Peptidylprolyl isomerase B & $\begin{array}{l}\text { F: GGCCCAAAGTCACTGTCAAGGTGT } \\
\text { R: AAAGAGACCGATGACCACCCGG }\end{array}$ \\
\hline NM_174760 & RPL10 & Ribosomal protein L10 & $\begin{array}{l}\text { F: TTCCTGGAGGGCGTCCGCAAT } \\
\text { R: AAGCCAGGACGCGCTTGTACC }\end{array}$ \\
\hline
\end{tabular}

F, forward; $R$, reverse. 
by F-tests using type III sums of squares. The PDIFF command incorporating the Tukey test was applied to evaluate pairwise comparisons between treatment means.

\section{Declaration of interest}

The authors declare that there is no conflict of interest that could be perceived as prejudicing the impartiality of the research reported.

\section{Funding}

This work was supported by Science Foundation Ireland (07/SRC/B1156). DR was supported by the Spanish Ministry of Science and Innovation (AGL2009-11810). VM was partially supported by a Short Term Scientific Mission from COST-GEMINI Action (FA0702-7374).

\section{Acknowledgements}

The authors thank Mary Wade and Penny Furney for their excellent technical assistance.

\section{References}

Adams GP, Kot K, Smith CA \& Ginther OJ 1993 Selection of a dominant follicle and suppression of follicular-growth in Heifers. Animal Reproduction Science 30 259-271. (doi:10.1016/0378-4320(93) 90076-4)

Bauersachs S, Ulbrich SE, Zakhartchenko V, Minten M, Reichenbach M, Reichenbach HD, Blum H, Spencer TE \& Wolf E 2009 The endometrium responds differently to cloned versus fertilized embryos. PNAS 106 5681-5686. (doi:10.1073/pnas.0811841106)

Beckers NG, Macklon NS, Eijkemans MJ, Ludwig M, Felberbaum RE, Diedrich K, Bustion S, Loumaye E \& Fauser BC 2003 Nonsupplemented luteal phase characteristics after the administration of recombinant human chorionic gonadotropin, recombinant luteinizing hormone, or gonadotropin-releasing hormone $(\mathrm{GnRH})$ agonist to induce final oocyte maturation in in vitro fertilization patients after ovarian stimulation with recombinant follicle-stimulating hormone and $\mathrm{GnRH}$ antagonist cotreatment. Journal of Clinical Endocrinology and Metabolism 88 4186-4192. (doi:10.1210/jc.2002-021953)

Bordignon V, Morin N, Durocher J, Bousquet D \& Smith LC 1997 GnRH improves the recovery rate and the in vitro developmental competence of oocytes obtained by transvaginal follicular aspiration from superstimulated heifers. Theriogenology 48 291-298. (doi:10.1016/S0093691X(97)84076-9)

Bourgain C, Devroey P, Van Waesberghe L, Smitz J \& Van Steirteghem AC 1990 Effects of natural progesterone on the morphology of the endometrium in patients with primary ovarian failure. Human Reproduction 5 537-543.

Brandao DO, Maddox-Hyttel P, Lovendahl P, Rumpf R, Stringfellow D \& Callesen H 2004 Post hatching development: a novel system for extended in vitro culture of bovine embryos. Biology of Reproduction 71 2048-2055. (doi:10.1095/biolreprod.103.025916)

Callesen H, Greve T \& Hyttel P 1986 Preovulatory endocrinology and oocyte maturation in superovulated cattle. Theriogenology 25 71-86. (doi:10.1016/0093-691X(86)90184-6)

Carter F, Forde N, Duffy P, Wade M, Fair T, Crowe MA, Evans AC, Kenny DA, Roche JF \& Lonergan P 2008 Effect of increasing progesterone concentration from day 3 of pregnancy on subsequent embryo survival and development in beef heifers. Reproduction, Fertility, and Development 20 368-375. (doi:10.1071/RD07204)

Check JH, Nowroozi K, Chase J, Nazari A \& Braithwaite C 1992 Comparison of pregnancy rates following in vitro fertilization-embryo transfer between the donors and the recipients in a donor oocyte program. Journal of Assisted Reproduction and Genetics 9 248-250. (doi:10.1007/BF01203822)

Clemente M, de La Fuente J, Fair T, Al Naib A, Gutierrez-Adan A, Roche JF, Rizos D \& Lonergan P 2009 Progesterone and conceptus elongation in cattle: a direct effect on the embryo or an indirect effect via the endometrium? Reproduction 138 507-517. (doi:10.1530/REP09-0152)

Fatemi HM, Popovic-Todorovic B, Papanikolaou E, Donoso P \& Devroey P 2007 An update of luteal phase support in stimulated IVF cycles. Human Reproduction Update 13 581-590. (doi:10.1093/ humupd/dmm021)

Fauser BC \& Devroey P 2003 Reproductive biology and IVF: ovarian stimulation and luteal phase consequences. Trends in Endocrinology and Metabolism 14 236-242. (doi:10.1016/S1043-2760(03)00075-4)

Forde N, Carter F, Fair T, Crowe MA, Evans AC, Spencer TE, Bazer FW, McBride R, Boland MP, O'Gaora P et al. 2009 Progesteroneregulated changes in endometrial gene expression contribute to advanced conceptus development in cattle. Biology of Reproduction 81 784-794. (doi:10.1095/biolreprod.108.074336)

Forde N, Beltman ME, Duffy GB, Duffy P, Mehta JP, O'Gaora P, Roche JF, Lonergan P \& Crowe MA 2011a Changes in the endometrial transcriptome during the bovine estrous cycle: effect of low circulating progesterone and consequences for conceptus elongation. Biology of Reproduction 84 266-278. (doi:10.1095/biolreprod.110.085910)

Forde N, Carter F, Spencer TE, Bazer FW, Sandra O, Mansouri-Attia N, Okumu LA, McGettigan PA, Mehta JP, McBride R et al. $2011 b$ Conceptus-induced changes in the endometrial transcriptome: how soon does the cow know she is pregnant? Biology of Reproduction 85 144-156. (doi:10.1095/biolreprod.110.090019)

Garcia J, Jones GS, Acosta AA \& Wright GL Jr 1981 Corpus luteum function after follicle aspiration for oocyte retrieval. Fertility and Sterility $\mathbf{3 6}$ 565-572.

Gray CA, Burghardt RC, Johnson GA, Bazer FW \& Spencer TE 2002 Evidence that absence of endometrial gland secretions in uterine gland knockout ewes compromises conceptus survival and elongation. Reproduction 124 289-300. (doi:10.1530/rep.0.1240289)

Griesinger G 2011 Editorial commentary: is it time to abandon progesterone supplementation of early pregnancy after IVF? Human Reproduction 26 1017-1019. (doi:10.1093/humrep/der013)

Hayashi KG, Matsui M, Acosta TJ, Kida K \& Miyamoto A 2006 Effect of the dominant follicle aspiration before or after luteinizing hormone surge on the corpus luteum formation in the cow. Journal of Reproduction and Development 52 129-135. (doi:10.1262/jrd.17049)

Heyman Y, Chavatte-Palmer P, LeBourhis D, Camous S, Vignon X \& Renard JP 2002 Frequency and occurrence of late-gestation losses from cattle cloned embryos. Biology of Reproduction 66 6-13. (doi:10.1095/ biolreprod66.1.6)

Hinrichs K, Rand WM \& Palmer E 1991 Effect of aspiration of the preovulatory follicle on luteinization, corpus luteum function, and peripheral plasma gonadotropin concentrations in the mare. Biology of Reproduction 44 292-298. (doi:10.1095/biolreprod44.2.292)

Jimenez-Krassel F, Folger JK, Ireland JLH, Smith GW, Hou X, Davis JS, Lonergan P, Evans ACO \& Ireland JJ 2009 Evidence that high variation in ovarian reserves of healthy young adults has a negative impact on the corpus luteum and endometrium during estrous cycles in cattle. Biology of Reproduction 80 1272-1281. (doi:10.1095/biolreprod.108. 075093)

Kerin JF, Broom TJ, Ralph MM, Edmonds DK, Warnes GM, Jeffrey R, Crocker JM, Godfrey B, Cox LW, Seamark RF et al. 1981 Human luteal phase function following oocyte aspiration from the immediately preovular graafian follicle of spontaneous ovular cycles. British Journal of Obstetrics and Gynaecology 88 1021-1028. (doi:10.1111/ j.1471-0528.1981.tb01691.x)

Kolibianakis EM \& Devroey P 2002 The luteal phase after ovarian stimulation. Reproductive Biomedicine Online 5 (Suppl 1) 26-35. (doi:10.1016/S1472-6483(11)60214-9)

Kolibianakis EM, Bourgain C, Platteau P, Albano C, Van Steirteghem AC \& Devroey P 2003 Abnormal endometrial development occurs during the luteal phase of nonsupplemented donor cycles treated with recombinant 
follicle-stimulating hormone and gonadotropin-releasing hormone antagonists. Fertility and Sterility 80 464-466. (doi:10.1016/S00150282(03)00663-0)

Kreitmann O, Nixon WE \& Hodgen GD 1981 Induced corpus luteum dysfunction after aspiration of the preovulatory follicle in monkeys. Fertility and Sterility 35 671-675.

Kyrou D, Fatemi HM, Zepiridis L, Riva A, Papanikolaou EG, Tarlatzis BC \& Devroey P 2011 Does cessation of progesterone supplementation during early pregnancy in patients treated with recFSH/GnRH antagonist affect ongoing pregnancy rates? A randomized controlled trial Human Reproduction 26 1020-1024. (doi:10.1093/humrep/der012)

Lamb GC, Stevenson JS, Kesler DJ, Garverick HA, Brown DR \& Salfen BE 2001 Inclusion of an intravaginal progesterone insert plus $\mathrm{GnRH}$ and prostaglandin F2alpha for ovulation control in postpartum suckled beef cows. Journal of Animal Science 79 2253-2259.

van de Leemput EE, Vos PL, Zeinstra EC, Bevers MM, van der Weijden GC \& Dieleman SJ 1999 Improved in vitro embryo development using in vivo matured oocytes from heifers superovulated with a controlled preovulatory LH surge. Theriogenology 52 335-349. (doi:10.1016/ S0093-691X(99)00133-8)

Mansouri-Attia N, Sandra O, Aubert J, Degrelle S, Everts RE, Giraud-Delville C, Heyman Y, Galio L, Hue I, Yang X et al. 2009 Endometrium as an early sensor of in vitro embryo manipulation technologies. PNAS 106 5687-5692. (doi:10.1073/pnas.0812722106)

Messinis IE, Messini CI \& Dafopoulos K 2009 Luteal-phase endocrinology. Reproductive Biomedicine Online 19 (Suppl 4) 4314.

Milvae RA, Alila HW, Bushmich SL \& Hansel W 1991 Bovine corpus luteum function after removal of granulosa cells from the preovulatory follicle. Domestic Animal Endocrinology 8 439-443. (doi:10.1016/ 0739-7240(91)90012-9)

Mozzaquatro FD, Verstegen JP, Douglas RH, Troedsson MH, DeLaCorte FD, Silva CA \& Rubin MI 2011 Luteal function induced by transvaginal ultrasonic-guided follicular aspiration in mares. Animal Reproduction Science 119 56-62. (doi:10.1016/j.anireprosci.2009.12.012)

Mussard ML, Burke CR, Behlke EJ, Gasser CL \& Day ML 2007 Influence of premature induction of a luteinizing hormone surge with gonadotropinreleasing hormone on ovulation, luteal function, and fertility in cattle. Journal of Animal Science 85 937-943. (doi:10.2527/jas.2006-592)

Nyboe Andersen A, Popovic-Todorovic B, Schmidt KT, Loft A, Lindhard A, Hojgaard A, Ziebe S, Hald F, Hauge B \& Toft B 2002 Progesterone supplementation during early gestations after IVF or ICSI has no effect on the delivery rates: a randomized controlled trial. Human Reproduction 17 357-361. (doi:10.1093/humrep/17.2.357)

Perry GA, Smith MF, Lucy MC, Green JA, Parks TE, MacNeil MD, Roberts AJ \& Geary TW 2005 Relationship between follicle size at insemination and pregnancy success. PNAS 102 5268-5273. (doi:10. 1073/pnas.0501700102)
Peters MW \& Pursley JR 2003 Timing of final GnRH of the Ovsynch protocol affects ovulatory follicle size, subsequent luteal function, and fertility in dairy cows. Theriogenology 60 1197-1204. (doi:10.1016/ S0093-691X(03)00120-1)

Pritts EA \& Atwood AK 2002 Luteal phase support in infertility treatment: a meta-analysis of the randomized trials. Human Reproduction $\mathbf{1 7}$ 2287-2299. (doi:10.1093/humrep/17.9.2287)

Rizos D, Ward F, Duffy P, Boland MP \& Lonergan P 2002 Consequences of bovine oocyte maturation, fertilization or early embryo development in vitro versus in vivo: implications for blastocyst yield and blastocyst quality. Molecular Reproduction and Development 61 234-248. (doi:10.1002/mrd.1153)

Rizos D, Scully S, Kelly A, Ealy AD, Moros R, Duffy P, AINaib A, Forde N \& Lonergan P 2012 Effect of administration of human chorionic gonadotrophin on day 5 post oestrus on corpus luteum characteristics, circulating progesterone and conceptus elongation in cattle. Reproduction, Fertility, and Development 24 472-481. (doi:10.1071/RD11139)

Schmidt KL, Ziebe S, Popovic B, Lindhard A, Loft A \& Andersen AN 2001 Progesterone supplementation during early gestation after in vitro fertilization has no effect on the delivery rate. Fertility and Sterility $\mathbf{7 5}$ 337-341. (doi:10.1016/S0015-0282(00)01709-X)

Spencer TE \& Gray CA 2006 Sheep uterine gland knockout (UGKO) model. Methods in Molecular Medicine 121 85-94.

Stafford-Bell MA \& Copeland CM 2001 Surrogacy in Australia: implantation rates have implications for embryo quality and uterine receptivity. Reproduction, Fertility, and Development 13 99-104. (doi:10.1071/ RD00044)

Stocco DM \& Clark BJ 1996 Role of the steroidogenic acute regulatory protein (StAR) in steroidogenesis. Biochemical Pharmacology $\mathbf{5 1}$ 197-205. (doi:10.1016/0006-2952(95)02093-4)

Stocco C, Telleria C \& Gibori G 2007 The molecular control of corpus luteum formation, function, and regression. Endocrine Reviews $\mathbf{2 8}$ 117-149. (doi:10.1210/er.2006-0022)

Vargyas J, Kletzky O \& Marrs RP 1986 The effect of laparoscopic follicular aspiration on ovarian steroidogenesis during the early preimplantation period. Fertility and Sterility 45 221-225.

Vejlsted M, Du Y, Vajta G \& Maddox-Hyttel P 2006 Post-hatching development of the porcine and bovine embryo-defining criteria for expected development in vivo and in vitro. Theriogenology 65 153-165. (doi:10.1016/j.theriogenology.2005.09.021)

Received 27 December 2011

First decision 24 January 2012

Revised manuscript received 5 February 2012

Accepted 24 February 2012 